\title{
Religious perspectives on Vaccination: Mandatory Covid-19 vaccine for SA Churches
}

\author{
Jonas Sello Thinane \\ Hebrew Senior Departmental Administrator \\ Humanities Faculty, University of the Free State \\ South Africa \\ E-mail: jsthinane@gmail.com \\ Orcid i.d: https://orcid.org/0000-0002-8522-8519 \\ Doi: https://doi.org/10.46222/pharosjot.10312
}

\begin{abstract}
In public health history, vaccinations have been seen as very helpful as they help protect societies from preventable diseases and save many lives around the world. Despite the fact that few religious groups oppose vaccination for a variety of reasons, almost all major religions in the world support vaccination as long as it complies with religious precepts for the preservation, protection, or well-being of livelihoods. However, during the surge of Covid-19 outbreak in South Africa and elsewhere, governments witnessed unprecedented hesitancy and opposition to the Covid-19 vaccination by the general public. Those who opposed the Covid-19 vaccine cited multiple concerns or reasons, ranging from possible side effects, adverse events, vaccine safety, vaccine effectiveness, conspiracy theories, and religious or cultural reasons. Based on a literature search, this paper attempts to discuss various religious views on the subject of vaccination in general and subsequently make use of such perspectives to support calls for a compulsory Covid-19 vaccination, especially for South African churches. This is a timely topic of central concern as it seeks to politely dispel religious misunderstandings and confusion that could arise as a result of debates on mandatory vaccines for Covid-19. Health and religion will be brought together to shape the ongoing discussions about the moral urgency of a mandatory Covid-19 vaccination in South Africa.
\end{abstract}

Keywords: Religion, Mandatory, Covid-19, Vaccination, Churches

\section{Introduction}

The coronavirus disease is said to originated from Wuhan, China, by the end of December 2019, hence it was codenamed or shortened to the Covid-19, which is caused by a severe acute respiratory syndrome coronavirus 2 (SARS-CoV-2) that has reached pandemic proportions. This infected millions of people around the world in 2019 and advanced in 2020, 2021 and it is still around in the form of a variant termed Omicron. Several reports suggested that this virus emerged from Wuhan, China (Florindo, 2020: 630) in December 2019. In February 2020 there were around 261,805 positive cases with 958 deaths worldwide (Syed Alwi et al., 2021: 1). That number would rise to 118,000 positive cases worldwide and claim about 4,291 lives by early March. In anticipation of these numbers increasing, the World Health Organization (WHO) declared the Covid-19 outbreak a health emergency or a pandemic on March 11, 2020 (WHO, 2020: online).

At the time of writing this paper, there was no curative treatment for Covid-19 infection, but only the availability of approved vaccines to contain the pandemic. In order for governments to protect lives that would otherwise be claimed by this virus, herd immunity is required, which requires vaccination of a significant portion of citizens or the population. In anticipation of high vaccine adoption when this virus started, many scholars including Jaja et al (2020), and Thinane (2021) had confidence in that the only answer to the Covid-19 pandemic was the 
arrival of suitable vaccines. In particular, Thinane (2021) went so far as to ask the South African churches to join resources with the country's government to ensure an equitable distribution of vaccines to South Africans. These scholars did not anticipate that the introduction of vaccines would encounter social hesitation, delays and vicious conspiracy theories aimed at discrediting the achievements of medical science and further deterring the people of South Africa from vaccinating against Covid-19.

This paper seeks to examine some religious perspectives on vaccinations in general and to deductively formulate religious standpoints on the question of the Covid-19 vaccine. Essentially, this paper is then intended to provide contextual bases for questions about religious concerns about vaccines and the role of various major religions in promoting public health through vaccination. It is important to note that while the selected list of major religions in this paper is not exhaustive, it is merely a workable selection of a limited range of religious views on the issue of vaccination in general, and Covid-19 vaccination in particular. Among these religions, Christianity is prioritized and discussed in more detail, as it is the leading religion, especially in South Africa, and the largest in the world (WPR, 2021: online).

This paper only recommends considering mandatory Covid-19 vaccination for Christian churches, without suggesting how to proceed with these mandates, as this could lead to further considerations such as legal implications and enforceability of such mandates. The first section only focuses on the general proposal to consider mandatory Covid-19 vaccination by religious organizations in general and Christian churches in particular. The next section consists of at least three sub-sections. First, the history of vaccination in general is discussed and compared with incidents against vaccination. Second, an overview of some important religious views on vaccination in general is discussed with the intention of advancing them in the context of Covid-19 vaccination. Third, the views of some Christian denominations such as the Roman Catholic Church, Orthodox Churches and Protestant Churches are taken into account to propose a strong case for mandatory Covid-19 vaccination for churches in South Africa.

\section{History of vaccination}

According to Vanderslott, Dadonaite and Roser (2013), vaccination was initially generally referred to as vaccination or variolation in the past. This practice involved the age-old technique of deliberately blowing dried smallpox scab into the nose of a healthy person in order to vaccinate them against smallpox (Vanderslott, Dadonaite \& Roser, 2013: online).

The literature overwhelmingly suggested that the earliest data on vaccination came perhaps in late $17^{\text {th }}$ century, in May 1796 to be precise, when the English physician Edward Jenner developed the world's first ever vaccine by infecting fluid derived from people who were infected with cowpox to prevent human disease of smallpox. As the result, those vaccinated with cowpox developed immunity or body's ability to prevent smallpox and only suffered mild and non-fatal outcomes. In the words of Smith (2011) Jenner: 'discovered that it was possible to protect against the dread disease Small Pox by injecting material taken from a similar pox disease of cows' (Smith, 2011:1). Back then (1973-1800) smallpox was thought to have become one of the most feared diseases, but millions of lives were saved with Jenner's discovery (Henderson, 1997: 112-121; Zainudin et al., 2018: 273-279). Henderson (1997) observed that many children died before the age of 10 and of those who died $40 \%$ died of smallpox. Jenner's discovery provided the scientific basis for other subsequent vaccines to prevent various diseases and stimulate the production of antibodies. According to Stern and Markel (2005), the French chemist, Louis Pasteur developed what came to be called a rabies vaccine in 1885 which prevented rabies that was caused by a dog bite or a bat bite. It was Pasteur who conceived the definition of vaccine as an interruption of live or incapacitated microorganisms or fractions thereof administered to prompt immunity and avert infectious disease (Stern \& Markel, 2005:613). But already in the late 18th century, some religious leaders opposed vaccines arguing that it was wrong to hinder God's will by preventing disease, 
while others expressed concern about the idea that humans were vaccinated with a substance derived from an animal (Henderson, 1997: 117-120).

\section{Anti-vaccination}

The above section has shown that for the longest time in public health history, vaccination has been considered by health and medical scientists to be one of the best achievements in all of public health history. Nevertheless resistance or hesitancy to vaccinations has also existed since the development of the first vaccine.

According to Cooper et al. (2021), there was always hesitation and rejection of vaccines in global outbreaks. Vaccine-preventable diseases such as measles, $\mathrm{H} 1 \mathrm{~N} 1$ pandemic influenza 2009, human papillomavirus (HPV), polio and many other diseases have recently experienced mistrust, hesitation, questioning and resistance worldwide (Cooper et al., 2021: 921-922 ). Similar observations are made by Stern and Markel (2005) who observed that during the peak periods of historical diseases and infections, vaccine reluctance, safety concerns, and many other challenges countered vaccine initiatives (Stern \& Markel, 2005: 611).

According to Burger et al. (2021), among of those who responded negatively or hesitantly towards taking Covid-19 vaccine, $31 \%$ comprised of those who were worried about vaccine's possible side effects, $21 \%$ being those who refused to believe the efficacy of vaccines which are developed within a short space of time, and $18 \%$ comprising of those who did not trust vaccines in general (Burger et al., 2021:2).

\section{Religious views on vaccination}

In most societies, religious organisations are very influential and the role they play or their impact on members of the society cannot be downplayed nor undermined. The excellent work of Williams, Nussbaum and O'Leary (2019) accurately opined that major faith traditions have historically been very supportive of vaccinations. In line with this, the work of Skold (1996) found that during the early 19th century, when smallpox vaccination became compulsory in Sweden, the clergy worked with the authorities to introduce measures to encourage believers to be vaccinated (Skold, 1996: 247-262). Williams, Nussbaum, and OLeary (2019) alike, however, found that at critical moments in history, a number of religious organizations joined the anti-vaccination voices (Williams, Nussbaum \& OLeary, 2019: 1).

Africans in general (Paris, 1993: 114-124; Mbiti, 1999: 1-15; Agbiji \& Swart, 2015: 1-9) and South Africans in particular are deeply religious, although challenges such as the Covid-19 Pandemics continue to weaken religious inclination (Kotze \& Loubser, 2017: 1-11; Chipkin \& Leatt, 2011: 39-42; Chukwuma, 2021: 1-8). Hence, it is the view of this paper that the role which religion or religious institutions such as Christian churches can play in reassuring or encouraging their members to recognize the importance of vaccines in general, or Covid-19 vaccines in particular, is great. They can reassure or encouraging their members to recognize the importance of vaccines in general, and Covid-19 vaccines in particular cannot be undermined nor be ignored by discussions on Covid-19 vaccines in general.

Accordingly, the following section first examines various religious views, particularly on vaccines in general, and finally it examines how Christianity, as the world's leading religion, deals with vaccine issues. The intent behind this comprehensive overview is to provide an educated assessment of the worldwide religious probable views about the mandatory Covid19 vaccine, particularly Christian views on the probabilities for the mandatory Covid-19 vaccination guidelines for churches.

\section{Islamic views}

This section looks into the attitudes of Muslims towards vaccination in general. Sulaiman (2014) pointed that some of Muslim's grievances against vaccination originated from allegations of 'treachery intentions' by vaccine producers. One of such alleged plots involved 
the allegation that the polio vaccine was made of substances which would in a long run render females infertile, an alleged plot led by the United State of America (USA) to depopulate Africa. Furthermore, it was also alleged that Oral Polio Vaccine (OPV) was obtained from the monkey tissue, making it to be forbidden to Muslim community. However, the very argument is dispelled by the office of the Grand Sheikh who affirmed that, contrary to the rumour of infertility, decades after this vaccine was administered, girls who were vaccinated are now married and were able to conceive (Sulaiman, 2014). In regard to OPV being obtained from monkey, the Grand Mufti of Al Azhar University in Cairo argued that since the tissue is transformed into something else, it is no longer a monkey tissue, but that which is necessary to preserve health. Sulaiman further outlined several issues that some Islamic scholars raise in relation to vaccination. Such issues includes but not limited to arguments about the faultless creation of Allah suggesting that Allah built every human body to be perfect enough to withstand all infectious diseases and about readily available provisions of Allah such as mother's breast milk for kids and other food that contains the required nutrients which are meant to strengthen the human immune system against various disease (Sulaiman, 2014:123,125-126).

According to Sulaiman (2014), the laws of Allah recognizes the need for prevention of various ailments by all available means. He indicated that the Holy Quran (Muslim sacred scripture) makes use of the concept of prevention in many ways to show the importance of taking preventive action against ailments, such examples include but not limited to (Q2:201, 3:16) wherein preventive action against entering the fire of hell or punishment is encouraged, (Q46:9) which speaks of prevention against bad acts, and (Q16:81) which is about prevention against harm or injury (Sulaiman, 2014:124). To further stress the importance of vaccines as a means to prevent diseases, Islamic Scholars maintained that Shariah law allows the use of medication and other discovered remedies to preserve the health of oneself/others as it is forbidden to anyone to do harm to either him/herself or others. They argued that Shariah's teachings encourages believers to vaccinate against diseases to preserve lives. It is for this reason that Sulaiman concluded: 'Immunization as a preventive mechanism is Halal in Islam based on the teachings of the Quran and the Hadith (Sulaiman, 2014:126,130). This is based upon the Sharia's fundamental rule forbidding harm on oneself or others. Further, these scholars argued that various teachings of Sharia encourage its believers to seek treatment and explore all efforts to preserve human health. As such, vaccination is believed to serve the purposes of Sharia in many ways. Additionally, the Grand Mufti of Al Azhar University in Egypt, indicated that respectively in 1992 and 2005 when the Islamic council in Cairo was presented with the question of vaccination, it decreed that vaccination is in line with Islamic decree as it protects lives. This view is supported by the Grand Mufti of the kingdom of Saudi Arabia (19931999), Abd al-Aziz Bin Baz who argued that there is nothing wrong with vaccines since they are merely used to ward off the preventable disease which could otherwise claim many lives (Ebrahim, 2014:49; Sulaiman, 2014:126).

Similarly, Ebrahim (2014) also noted that vaccination fulfils about five objectives that are contained in the Shariah. Such objectives include preservation of religion and morality (hifz aldin); whereby those who are vaccinated will be able uphold and put into practice all the obligatory acts of worship, preservation of life and health (hifz al-nafs) as vaccines have been proven to preserve lives of millions of people and prevent diseases, preservation of progeny (hifz al-nasl) in that parents who allowed their children to be vaccinated fulfilled this objectives as they safeguarded them from succumbing to preventable diseases, preservation of intellect or sanity (hifz al-`aql) in that communities or citizens that are vaccinated live in harmony knowing that their protected from preventable diseases, and lastly, preservation of wealth (hifz al-mal) since vaccines are cost effective or economical interventions as they prevent diseases than to treat them. In conclusion, Ebrahim (2014) invoked Al-Ma'idah 5:32 as he concluded that in terms of the Quranic imperative to save lives, vaccination does not violate the Quran Divine injunctions, instead it fulfils such an imperative by saving human life against 
preventable diseases like tuberculosis, measles, polio and many other diseases that would otherwise kill multiple people indiscriminately (Ebrahim, 2014:46).

\section{Buddhist views}

Buddhists strongly believe in the Wheel of Rebirth or the beginning-less cycle of repeated birth. According to this belief, life is set to be reincarnated or re-embodied in line with Karma (fate) that a person accumulates while living (Tenzing, 1996:13-14). The Wheel of Rebirth keeps on rolling and will only stop once all karma has been fully exhausted (Nirvāna - the ultimate state of salvation) or once one has accumulated the ultimate enlightenment (Numrich, 2001:2). This means every dying is immediately followed by new birth or as Metzner (1996) puts it: 'Every birth and every rebirth is preceded by a dying. Every transition in a human lifecycle can be thought of metaphorically as a dying and being reborn' (Metzner 1996:158) or better still, as Numrich (2001) would put it: 'that human existence is part of an ongoing cycle of multiple lifetimes' (Numrich, 2001:2). For every Buddhist to achieve such a state (Nirvāna), he/she must carefully observe the 8-fold Path and the Buddhist morality embraced by ten precepts or teachings which are somehow analogous to the second half of Judaism and Christian Ten Commandments. They all speak to behaviours that believers should avoid.

The first of these precepts prohibit any taking of life or the moral commitment not to destroy life. According to Numrich (2001) this commitment being the first precept, is the heart of Buddhist ethics (Numrich, 2001:3). This teaching forms the basis upon which Buddhists formulate their moral standpoint with regard to vaccination in the interest of public health, particularly when such vaccine prevent fatal diseases as it is the case with Covid-19 vaccines. To further emphasise the centrality of healing practices within Buddha religion, Brabenstein (2013) referred to Rinpoche (1994) who described the importance of a prayer of the Healing Buddha which sought to prevent disease which are not even experienced (Brabenstein, 2013:2013). Before even attempting to formulate opinion on medical measures, Buddhists would firstly determine whether or not the intention behind the said medical means violates or is in line with the first precept of destroying life. Once this is determined, its significance outweigh all other arguments or adverse theories. It is precisely for this reason scholars such as Pelčić et al (2016) submitted in general terms that Buddhist adherents will make use of any available vaccine to protect their own health and that of others in the case of fatal infectious diseases (Pelčić et al., 2016:518-519).

Historically the concept of immunisation has been widely accepted predominantly by Buddhists. According to Brabenstein (2013), a Buddhist nun (Bhikkhuni) during 1022-1063 CE would crush scabs collected from a person infected with smallpox into a powder and blow it into the nostrils of one who is without smallpox to induce immunity (Brabenstein, 2013:2013). Furthermore, according to the Immunisation Advisory Centre (IAC 2016), in the past, Buddhist monks would drink snake venom to grant immunity to snake bite (IAC 2016: online). In fact, this is substantiated by scholars such as Cha (2012) and Kiboneka (2021) who submitted that the practice of immunization prefigured by Edward Jenner during the $17^{\text {th }}$ century, Buddhist monks drank snake venom to acquire immunity against snake bite and even smeared skin tears with cowpox to prevent smallpox (Kiboneka, 2021:233). Not long ago, in 2010, His Holiness, the Nobel Laureate and the spiritual leader of the Tibetan People, the $14^{\text {th }}$ Dalai Lama at the Buddhism's holiest site, Bihar state in East India, gave his support to the polio vaccine as he helped to launch the drive to eradicate polio using the new bivalent oral polio vaccine to protect children from surviving types of poliovirus (Krieger, 2015: online). As a matter of fact, not long ago, the now 85-year-old Dalai Lama himself, along with ten other people who reside in his residence received his first shot of Covid-19 vaccine on 06 March 2021 at a hospital in the north Indian hill city of Dharamshala and further encouraged those eligible for vaccine to receive their immunizations. As he was given the Oxford Astrazeneca jab, he is quoted saying: 'This is very very helpful, very good' (BBC News, 2021: online), while elsewhere he is quoted saying: 'In order to prevent some serious problems, this injection is very, very helpful' (The Guardian, 2021: online). Generally speaking, Buddhists understand 
and stress the importance of saving lives by all available means, including the use of vaccines. In line with their first precept, they hypothetically will embrace Covid-19 vaccine as has been the case with His Holiness, the Dalai Lama.

\section{Hindu views}

The Persian word 'Hindu' means 'Indian', hence this community is largely associated with the Indian people or recognized as the national religion of India even though it consists mainly of Nepali and Indian people. Unlike other world religions which have known founders, arguably Hinduism has no known starting point nor specific founder hence its adherents refer to it as Sanatana Dharma (eternal tradition or immemorial way of right living) to distinguish it from all other religions with specific founder. It does not subscribe to one individual doctrine, scripture or set of teachings hence many scholars will refer to it as a family of religions with compilation of many traditions and philosophies (Werner, 2016:5). Slightly similar to Buddhists, Hindus believe in rounds or circle of rebirth, recognized as reincarnation, culminating in the ultimate reincarnation occurring in the form of a cow which explains why Hindus have special respect for cows and animal life in general. Furthermore, this explains why some adherents of this religion have been reported to have been reluctant to accept the use of cows to develop a vaccine (Wombwell et al., 2015:600). Unlike other major religions, Hinduism has both monotheistic (one God) and polytheistic (many Gods) (Woodburne, 1925:52-66; Byrne, 2007:15-27). It is true that the various denominations within Hindu religion vary in terms of adopted philosophies and practices. However, the four major branches of this religion (Shaiva, Vaishnava, Shakta and Smarta) all share a set of fundamental beliefs in accordance with the revelations in the Vedic sacred tests (Grabenstein, 2013:2013). Historically, the Hindu religion is known for its narratives, beliefs and rituals adopted from Vedic times in favour of human wellbeing or health, as it sought to respond to various health crises resulting from various diseases and illnesses (Sweetman \& Malik, 2016:194-211).

According to Sweetman and Malik (2016) at the time when smallpox was the deadliest disease in India along with cholera, pneumonia and malarial, Hindu upper and lower class doctors embraced the pre-Jennerian practice of vaccination as they injected Indians with infected dried pus that was extracted from human smallpox victims scabs to inoculate and ultimately immunize them against smallpox. This practice was incorporated in this religion to such an extent that by around mid-19 ${ }^{\text {th }}$ century it was presented as an act of worship to which a lack of conformity resulted in the rage of a goddess (Sweetman \& Malik, 2016:206-208). It is no accident that Tyagi and Carley (2020) upon assessing the likelihood of accepting Covid-19 vaccination by first identifying religious prominent leaders on Twitter to premise the direction that religious followers might take, found that most Hindus are in fact likely to vaccinate against Covid-19, more than those who will choose not to (Tygi \&Carley, 2020:1-12). Similarly, a study by Williams et al. (2020) also found that most Hindu followers are likely to take a Covid-19 vaccine as opposed to abstaining from it (Williams et al., 2020:2800-2808).

\section{Judaisms views}

Judaism, or the Jewish faith, has been identified by most scholars for years as the oldest monotheistic religion in the world. Believers in this religion believe in a God who is known to have revealed himself through ancient prophets. Some scholars believe that this religion was founded in 538 BCE shortly after the return of the Israelites from Babylon in the Middle East (Helble, 2007). This religion is strictly regulated by the Torah as its holy scripture, which consists of the first five books of the Hebrew Bible, namely Genesis, Exodus, Leviticus, Numbers, and Deuteronomy.

It has been shown by some scholars that multiple Jewish rabbis have always preferred or supported vaccination despite the reality that a few people have died from vaccination procedures. According to Rashi (2020), many years before Edward Jenner developed the safe vaccination, Rabbi Abraham Hamburg in London published a book with the tittle 'Aleh Terufah' meaning Leaf of Medication. In this book, he discussed the important question on 
whether or not it was correct to vaccinate since some babies died due to vaccination. After describing how both his own son and daughter died from smallpox, he then argued that even if few children die due to vaccination, such reality does not dismiss the usefulness of vaccination for public health. He further argued that useful medical practices that contribute to public health and healing cannot be abandoned simply because only a few out of many die from such medical procedures. In fact, one of the most important rabbis in Italy, Rabbi Ishmael Hocohen of Modena, is said to have once written that it is important for children to be vaccinated against smallpox despite the fears that one in a thousand of them might die from the procedure. This sentiment is substantiated by the $19^{\text {th }}$ century leading Ashkenazi rabbi, Rabbi Yisrael Lipschitz who once ruled that it is proper to vaccinate since the danger of refusing vaccination is much greater than the danger that comes as the result of vaccination itself (Rashi, 2020:217-219). In fact, to put this more clearly, Bush (2012) wrote: 'Rav Yisrael Lifshitz ruled that even though slight risks do exist, the benefit of vaccination far outweighs the risk and they are permitted according to halakhah (the collective body of Jewish religious laws) (Bush, 2012:186). Therefore. It is safe to anticipate that most Jewish rabbis will support the need for mandatory Covid-19 vaccination as opposed to allowing a few adverse incidents to hinder the interests of public health in general terms. In South Africa, the Union of Orthodox Synagogues, along with other religious organizations, has launched a movement called the \#VaxuMzansi Campaign with the express aim of promoting efforts to ensure that at least $70 \%$ of their communities are vaccinated against the Covid-19 virus (Githahu, 2021:online).

\section{Christian views}

Christianity can be described as the world's largest monotheistic religion that is based on the teachings, life and death of Jesus of Nazareth as expressed within the four canonical gospels of the bible. Historically, Christianity began over 2000 years ago within the broader history of Graeco-Roman culture as part of the history of Judaism and grew into being the largest religion in the world (Fredriksen, 2003:35-63; Cohen, 2006:7-15,120-121).

According to scholars such as Grabenstein (2013), Berenbaum (2014) and Palazzani (2018), there is a slight exception of few churches which have historically rejected vaccination citing scriptural and various reasons. Scriptural verses cited against vaccination include but are not limited to Matthew 10:7-8, Mark 2:17, Mark 5:34, I Corinthians 3:16 and many others (Berenbaum, 2014:13-14). However, ultimately some of these churches like the Jehovah's Witnesses in 1952 began to realize the significance of vaccination for public health (Palazzani, 2018:19), (Occupational Health Clinic 2021: online). That being the case still, several major Christian denominations which include but are not limited to only such as Roman Catholicism, Eastern Orthodoxy, Baptist Churches, The Church of Jesus Christ of Latter-day Saints, Episcopalian, Methodists, Anglicans, Pentecostals, Seventh-Day Adventists, Presbyterian, and possibly many others have no canonical or scriptural objections to the broader use of vaccines. Palazzani (2018) argues that for Christian adherents and in the light of Christian creation-fall-redemption-restoration framework, vaccination in general forms or means offering a Christian service to humanity since the idea behind it, particularly as it relates to protecting oneself and others in the process, is consistent with number of Christian principles of loving your neighbour as yourself (Matthew 22; James 2) and the example of the good Samaritan who was kind to a stranger (Luke 10) (Grabenstein, 2013:2015). To support this analogy Palazzani (2018) puts it 'The legitimacy of vaccination is strictly linked also to the principle of solidarity, expressed in the Christian perspective by the prescription to love others (our neighbours) as oneself (Nicolaides, 2010; Palazzani, 2018:16).

\section{- Roman Catholicism on vaccines}

The Roman Catholic Church is the oldest Christian church and arguably the largest organized Christian community of all other Christian denominations (Ryall, 2001:41-58). Justified by its doctrinal teachings that abortion is immoral, Catholics express concern that certain vaccines are obtained from aborted foetal tissue. These vaccines will include but not limited to vaccines 
against rubella (Meruvax, M-R-vax, Rudivax), chicken pox vaccines (Varivax) and vaccines against hepatitis (A-Vaqta and Havrix) (Pelčić et al., 2016:516-517). According to Wombwell et al., (2015), if Catholics were to agree with the use of these type of vaccines, this will create an impression that they passively support abortion (Wombwell et al., 2015:600). But, the Catholic stand on this was that during the absence of alternative vaccines, the benefits of using it as it was are far more important for the health of the individual and the community within which they live (Erlingheuser, 2019:1). However, at this juncture it is important to mention that this practice has not been repeated since decades ago (CRPC, 2016:4). That being said, Catholics generally advocate the use of vaccines for most preventable diseases. The Roman Catholic Church, as it is perceived by Catholics as a symbol of the early Christian tradition and a mother church along with Orthodoxy, from which other Christian denominations emerged, is led by the Pope, who according to his teaching has the highest ecclesiastical authority on earth. Attempts to convey Catholic views on vaccination should look no further than the papacy. On 13 January 2021 Pope Francis reportedly urged people to get vaccinated against Covid-19 on a public platform. In the words of Watkins (2021): 'Pope Francis launches a powerful appeal for people to get vaccinated with approved Covid-19 vaccines, calling it 'an act of love" (Watkins, 2021: online). Responding to this act, Archbishop Romulo Valles, The president of the Catholic Bishops' Conference of the Philippines (CBCP) praised the Pope for being the good example to his flock (Gopez, 2021:330). These statements support the view of Engin and Vezzoni (2020), predicted that Catholic support for the Covid-19 vaccine will be based on Catholic teachings that encourage or ask believers to always do everything possible for the common good (Engin \& Vezzoni, 2020:161). Meanwhile, the Roman Catholic Bishops of Wisconsin in America on 20 August 2021 issued a statement reiterating Pope Francis' statement which stated that 'Humanity has a history of friendship with vaccines'. The statement furthers emphasised that vaccination in general is permissible and recognized by the Catholic Church as it serves the Christian common good (WCC, 2021:16).

\section{- Orthodox Churches on vaccines}

The Eastern Orthodox Church and Oriental Orthodox churches are among the leading largest branches of Christian religion after Roman Catholic. This church shareS very similar theology and practices with Roman Catholicism (Prodromou, 2004:62-75). According to Palazzani (2018), the Orthodox Church generally believes vaccines are legitimate as they seek to make better health for everyone. The Orthodox do of course believe in the concept of guardian angels and that Jesus Christ has appointed these to serve humanity and protect them to wise choices if they are deserving (See Ndlovu \& Nicolaides, 2021). Nicolaides, (2021) also argues that the Holy Eucharist is for the 'people of God' and thus Christians are enlightened to be partakers of what God blesses people to offer them, such as medications.

In Russia, a country where the Orthodox Church has a large following, its synod took place in September 2008 under the theme 'Vaccine's Prevention of Paediatric Problems and Ways of Making Decision', While recognizing the possibility that some vaccines could be dangerous, the Synod essentially recognized that vaccines play an important role in preventing infectious diseases from turning into pandemics. Through its official statement, this church condemned those who speak out against vaccinations and even forbade any promotion of antivaccinations in its monasteries and temples (Palazzani, 2018: 18-19). It is therefore no coincidence that in July 2021 this church strongly came out against those who refused to be vaccinated against Covid-19 and labelled them sinners who will be responsible for the deaths of many people who will die from Covid-19. Nicolaides (2012) a an Orthodox scholar, argues that God absolved all of humanity through total agape, thus giving doctors and scientists skills to support humanity, after all It was for the reason that the justifying work was finished that resurrection was made possible. Failing this, all would remain under the supremacy of death.

The bishop of the Russian Orthodox Church outside Russia, Metropolitan of Eastern Europe and New York, Bishop Hilarion Kapral, was quoted as saying the refusal to vaccinate against Covid-19 was: 
A sin for which they will have to atone throughout their lives...I see situations every day where people visit a priest in order to confess that they had refused to vaccinate themselves or their close ones and unwillingly caused someone's death...The sin is thinking of oneself but not of another person (Reuters, 2021:online).

For similar reasons, the Bishop of the Ecumenical Patriarchate of Constantinople Archbishop Elpidophoros refused to endorse religious exemptions from COVID-19 vaccine mandates, but instead encouraged people to listen to medical experts and avoid the false unscientific narratives about Covid-19 vaccinations (Smith, 2021:online). However, there have also been numerous influential archbishops and clerics frequently telling the flock not to get vaccinated, and there are also some who refuse to allow people into church if they are wearing a mask or have had a Covi-19 vaccine. The Greek Orthodox Holy Synod recommended the "free choice of vaccination as the exclusive and scientifically verified solution to break the spread of the virus," as well as "vigilance in prayers" and "frequent participation in worship." However the Holy Synod later sent out a circular to be read during Sunday's services, telling Orthodox adherents that the vaccine does not contradict what the church says and it urged the faithful to follow doctors' instructions.

\begin{abstract}
Members of the clergy have never been obliged to wear masks. Churches were among the first buildings in the country to reopen after both lockdowns, even as the rest of Greece remained indoors.

Rules that applied to everyone else, like wearing a mask or keeping safe distances, were never really applied in churches. Even a directive to hold Easter services earlier than the usual midnight, because of a nationwide curfew, was disobeyed. (Stamouli, 2021)
\end{abstract}

\title{
- Protestantism on vaccines
}

Protestantism can be described as a branch of Christianity that emerged as a result of Martin Luther's response to mediaeval Roman Catholic teachings and practices in the 16th century (Zakai, 1987; Gerrish, 2004). These churches includes but not limited to Reformed Churches, Methodist Churches, and Anglican Churches.

An exception of a small group of protestant churches considers the use of vaccination to be meddling with the work of God as they strongly believe no one should hinder or disturb someone's predestined fate since such is according or in line with divine providence (Hussain et al., 2018:4). However, these views are countered by the argument of many people who believe that God blessed doctors with wisdom and knowledge to create various medical interventions to prolong livelihoods in general (De Haas \& Mud, 2020:30). According to Ruijs et al., (2012), as early as in 1823, Abraham Capadose, who was then an orthodox protestant physician, recorded his objections to vaccination by first pointing to possible side-effects of smallpox vaccination and secondly arguing that it is wrong for anyone to inject a healthy body with disease to prevent the infection of the same disease (Ruijs et al., 2012:2; De Haas \& Mud, 2020:30). That being the case, the majority of protestant churches, particularly the orthodox protestant churches leave the decision to either vaccinate or not in the capable hands of individual members (Ruijs et al., 2012:1-10), where the majority of opt or advocate for the use of vaccines to prevent further spread of virus infections and fatal causalities. This change happened after the Dutch society in Netherlands experienced plagues of vaccine preventable diseases largely targeting those who refused vaccination. These outbreaks included poliomyelitis that lasted from 1992 to 1993 , measles from 1999 to 2000 , rubella from 2004 to 2005, mumps from 2007 to 2008 and measles in 2013 (Spaan et al., 2017:524,529).

Several Reformed Churches in the United States (USA) from the onset expressed their provaccine intentions. Shortly after its consultation with medical experts in 2016, the City Reformed Presbyterian Church (CRPC) published its official statement recommending parents to put their children on a vaccine schedule as per medical authorities' recommendation 
(CRPC, 2016:1-9). As if responding to this call, just three weeks after the first Covid-19 vaccine became available on January 5, 2021, staff and elderly residents (including 104 old Evelyn Arndt) of the Reformed Church Home (RCH) in New Jersey reportedly received their first of two doses of Pfizer injection to protect themselves individually and each other as a community from the virus ${ }^{1}$. Wisconsin Council of Churches (WCC) in its 2021 September report themed 'With one body and one Spirit: Returning to Church 3.0' included the Reformed Church in America statement saying: 'The denomination does not have a formal or informal stance on vaccines, vaccinations or exemptions. The denomination is a member tradition of the National Council of Churches, which is part of the core group of Faiths4Vaccines' (WCC, 2021:16).

The WCC further reflected official statements from several of its Methodist member churches such as the United Methodist Church (UMC) and Christian Methodist Episcopal Church (CMEC). The UMC's connectional leadership reiterated its societal policy statement, which emphasizes that science cannot make authoritative statements about theological matters, nor can the theology of which the church be a part make authoritative statements about scientific issues such as Covid-19 vaccines. With this in mind, the UMC emphasised its support for vaccination and further indicated that it views the distribution of Covid-19 vaccines as a missionary priority for the Church as it seeks to end the suffering caused by the Covid-19 pandemic (WCC, 2021:16). In a similar fashion, the CMEC College of Bishops encouraged people to take the Covid-19 vaccination arguing that such act demonstrate love for one's family, friends and neighbours (WCC, 2021:14). In South Africa, as if to reject theologically unsubstantiated claims that faith and prayer alone will cure Covid-19, the Cape Towns' Central Methodist Mission has allegedly hoisted yellow banners for the vaccine with a message saying: The blood of Jesus will not save you From Covid: Get Vaccinated, Protect Our Healthcare Workers. Its clergyman, Reverend Alan Storey is quoted saying: 'Every single major religion and denomination is pro-vaccinations. Vaccines are safe and effective - they save lives, they reduce spreading, they reduce hospitalization' and further inviting people to vaccinate against Covid-19 to protect themselves, the vulnerable, those with comorbidities and the elderly (Stent, 2021 :online).

According to the Anglican Communion News Service (ACNS), several prominent Anglican clergymen such as the Secretary General of the Anglican Community, Dr. Josiah IdowuFearon; the Archbishop of Cape Town, Dr. Thabo Makgoba; Canadian Anglican Archbishop and Primate of the Anglican Church of Canada, Bishop Linda Nicholls; Welsh Anglican Archbishop and former lawyer, Archbishop John Davies; The Anglican Archbishop of Alexandria, Archbishop Mouneer Anis, and many others have reportedly added their signatures in a letter calling for a global increase in Covid-19 vaccine production while calling for an end to vaccine nationalism which came as an initiative of the People's Vaccine Alliance (ACNS, 2021:online). In South Africa, Archbishop Thabo Makgoba spoke at the opening of Southern Africa's provincial synod urging delegates to consider endorsing mandatory vaccination for Anglican clergy. He is quoted saying:

Anti-vaccine lobbyists defend their right not to be vaccinated, which is all well and good if they are willing to stay at home in isolation. But as soon as they move into spaces occupied by others, their rights become limited by the rights of other (Githahu, 2021:online).

On 24 September 2021, after the presentation made by the co-chair of South Africa's Ministerial Advisory Committee on Coronavirus, Professor Koleka Mlisana which raised concerns about the declining Covid-19 vaccination rates, despite few opposing voices, the Anglican Provincial Synod voted in favour of a resolution that declared Covid-19 vaccination to be mandatory for the churches' since they regularly visit vulnerable

\footnotetext{
${ }^{1}$ COVID-19 vaccinations bring hope to long-term residents, staff at Reformed Church Home - https://reformedchurchhome.com/wp-content/uploads/2021/04/suburbannews-covid-vaccination-clinic-article-january-13-2020.pdf
} 
congregants to provide pastoral care (AnglicanchurchSA, 2021:online). In Besent (2021), Archbishop Thabo Makgoba is quoted saying: 'The synod did debate the motion and the concern by some were the fact that being mandatory might actually create a psychological pushback from some clergy, but we are of the same mind that vaccination is important' (Besent, 2021:online).

\section{Covid-19 vaccine hesitancy}

It is first important to define what would constitute vaccine hesitancy in general and in relation to Covid-19. According to Dubé et al., (2014) vaccine hesitancy refers broadly to any delay in acceptance or refusal of vaccines during its availability. Vaccine-hesitant people may doubtfully delay decision to agree or refuse taking a vaccine (Dubé et al., 2014:6649). In a similar fashion, focusing on Covid-19 vaccine hesitancy, Wiysonge et al., (2021) offered a more comprehensive definition to describe vaccine hesitancy as the unwillingness by vaccineeligible groups to receive it while it is available and accessible. They further predicted that while vaccine hesitancy has always been the case in the past amidst diseases like polio, yellow fever, smallpox and many others, the harmful effects of vaccine hesitancy are to be more prevalent under Covid-19 pandemic than ever before (Wiysonge et al., 2021:1-2).

According to a study conducted by Syed Alwi et al. (2016) utilizing an online questionnaire in Malaysia, people who refused or were hesitant to accept Covid-19 vaccine cited assorted reasons ranging from vaccine side effects, its safety, its effectiveness considering the speed with which multiple prospective vaccines were developed, conspiracy theories, religious and cultural reasons. However, meanwhile this study foresaw possible hesitancy and refusal of this vaccine, at the same time the study arrived at a conclusion that the majority of people in that country would accept Covid-19 vaccine once implemented by the Malaysian government (Syed Alwi et al., 2016:1-11). Similarly, in relation to South Africa, a report by Cooper et al, (2021) indicated that several peer reviewed surveys such as COVID-SCORE global survey ${ }^{2}$, Africa Centres for Disease Control and Prevention(Africa CDC) survey ${ }^{3}$, Three rounds of Ipsos online survey ${ }^{4}$, COVID-19 democracy survey ${ }^{5}$, The Ask Afrika COVID-19 tracker study 6 , South African social attitudes survey ${ }^{7}$ and Council for Medical Schemes COVID-19 vaccine survey $^{8}$, all which were conducted from February 2020 to March 2021 conducted with a clear purpose to investigate the potential acceptance of Covid-19 vaccines by Africans in general and South Africans population in particular when compared to other countries. With few exceptions citing various concerns, these surveys found that the majority of South Africans were ready to accept a suitable Covid-19 vaccine once it was developed (Cooper et al, 2021:925-928). Similarly, study by Burger et al, (2021) found that about $71 \%$ of South African adults responded positively to taking a Covid-19 vaccine once it was available (Burger et al., 2021:1-2). However, the arrival of Covid-19 vaccines was met with every growing hesitancy and refusal from across the globe and in South Africa in particular. Similarly as it was the case with Malaysian people (indicated above), in South Africa there are those who either refused

\footnotetext{
${ }^{2}$ COVID-SCORE global survey - https://journals.plos.org/plosone/article?id=10.1371/journal.pone.0240011

${ }^{3}$ Africa Centres for Disease Control and Prevention site - https://africacdc.org/news-item/majority-ofafricans-would-take-a-safe-and-effective-covid-19-vaccine/

${ }^{4}$ Three rounds of Ipsos online survey - https://www.ipsos.com/en-za/three-four-adults-globally-say-theywould-get-vaccine-covid-19

${ }^{5}$ Covid-19 democracy survey - http://www.hsrc.ac.za/uploads/pageContent/1045979/2021-08-18\%20UJHSRC\%20R4\%20Report\%201\%20Vaccine\%20acceptance.pdf

${ }^{6}$ The Ask Afrika Covid-19 tracker study - https://www.askafrika.co.za/wp-content/uploads/2021/05/AskAfrika-COVID-19-Omnibus-Week-1-2021-GENDER.pdf

${ }^{7}$ South African Social Attitude Survey summary - http://www.hsrc.ac.za/en/news/latest-news/covid-19vaccination-train-begins-drive-to-inoculate-communities-in-remote-parts-sa

${ }^{8}$ Council for Medical Schemes COVID-19 vaccine survey results - https://www.moonstone.co.za/cms-releasesresults-of-covid-19-vaccines-survey-on-peoples-attitudes/
} 
or were reluctant to take the Covid-19 vaccine due to various reasons which included but which were not limited to the side effects of the vaccine, its safety, its effectiveness given the speed with which several prospective vaccines were being developed, conspiracy theories, religious and cultural reasons (Burger et al., 2021:1-12; Letšosa, 2021:7).

\section{Mandatory vaccination justification}

Another highly contagious viral disease similar to Covid-19 is smallpox, which started as early as the third century CE. It is similar in that it is transmitted from one person to another through respiratory droplets or through contact with the infected surface (Belongia \& Naleway, 2003:87). Smith et al, (2011) indicated that as early as in the eighteenth century, a number of countries enforced compulsory or mandatory vaccination laws, in particular requiring smallpox vaccination for the general public (Smith et al 2011:4). Similarly, Kling (2009), recorded that Europe and some several states in the USA introduced compulsory vaccination for smallpox during the early 1800s (Kling, 2009:178). In fact, Heymann and Aylward (2006) specifically point to 1807 as the year within which Europe made smallpox vaccination compulsory. Subsequently other countries, including African countries followed the trend of making it mandatory for families, school entry and younger kids to have vaccines (Heymann \& Aylward, 2006:2). In South Africa, both Mitchell (1922) and Gear (1986), indicated that small-pox first came to South Africa in $1713 \mathrm{CE}$ through a voyage from India leading to a fatal outbreak in 1755 CE for which in 1883 CE a Public Health Act making vaccination of smallpox mandatory was passed by the Cape Parliament. At round about the same time, the Free State, Transvaal and Natal too made smallpox vaccination to be mandatory (Gear, 1986:7; Mitchell, 1922:808809). While number of people through the history of smallpox vaccination opposed or questioned the constitutionality of making it compulsory, courts of law have always stood on the side of protecting public health. Among classical examples of this is the 1904 case of Jacobson v. Massachusetts ${ }^{9}$ referred to in Albert, Ostheimer and Breman (2001) excellent work wherein the U.S. Supreme Court on 20 February 1905 ruled that while the state can respect individual rights by not imposing laws in order to protect an individual, it could pass laws requiring or making smallpox vaccination mandatory in order to protect the public against a dangerous infectious disease (Albert, Ostheimer \& Breman, 2001:376). Though vaccination in general with the exception of yellow fever or smallpox vaccination in particular is no longer compulsory in South Africa, the reality is that some scholars still see it as somewhat a de facto mandatory vaccine as it is required for school admissions (Blignaut, 2013:38). Further, during those interval years prior to 1987 , mandatory smallpox vaccination assisted South Africa to contain its spread and subsequently prevented fatalities as it recorded in Gear (1986:7-10).

Yellow fever is another disease that has caused social and economic disruption in a similar way to Covid-19 in most of the world's societies. Without entertaining various claims on the geographical origin of Yellow Fever, for the purpose of this paper it is enough to mention that overwhelming literature suggest that Yellow Fever threatened human health from early $18^{\text {th }}$ century coinciding with the slave trade epoch until the early $20^{\text {th }}$ century (Monath \& Vasconcelos, 2015:160; Mir et al., 2017:1-2). Apparently this virus is believed to have been initially carried by mosquitos from one host to another, and hosts can be from one monkey to another or from monkey to humans and ultimately from one human to another (Miller et al., 1989:396-399; Hillyer \& Christensen, 2002:431-433). In the words of Woodall and Yuill (2016): "The disease was carried by Aedes aegypti mosquitoes breeding in freshwater kegs on board and cycled among the slaves below deck, and both humans and mosquitoes disembarked on arrival to spread havoc" (Woodal \& Yuill, 2016:96). According to Vainio and Cutts (1998), the first cases of yellow fever were found on the islands of the southern Caribbean Sea, Guadeloupe and in the Mexican state, Yukatan in 1648 CE (Vainio \& Cutts, 1998:16). Plotkin (2011), says this disease further occurred in a sporadic manner in almost 33 African countries

${ }^{9}$ https://supreme.justia.com/cases/federal/us/197/11/ - Jacobson v. Massachusetts, 197 U.S. 11 (1905) 
and 11 South American countries (Plotkin, 2011:8). Speaking of it as a plague that attacked like an army, Lee (1998) descriptively said:

The fever attacked suddenly, with fits of hot and cold, and violent pain in the head, neck, and back. Not only would the patient's eyes turn watery and yellow, but the whole face would change, appearing 'unnatural,' denoting 'anxiety' and 'dejection of mind (Lee, 1998:675).

According to Vainio and Cutts (1998), this virus attacks almost 200000 people while killing at least 30000 people each year across the world (Vainio \& Cutts, 1998:9). Woodal and Yuill (2016) documented that in $1800 \mathrm{CE}$ alone, this virus recorded 60000 fatal cases in Europe (Woodal \& Yuill, 2016:98). Though at the time medical scientists did not understand many aspects of this virus, by the early periods of the $19^{\text {th }}$ century or 1937 to be exact, the capable vaccine was developed to help contain the spread and save lives (Frierson, 2010:77-79; Vanderslott \& Marks, 2020). In line with the World Health Organization recommendation, several countries across the world including South Africa, mandatorily require yellow fever vaccination from those travelling from high risk countries (Vanderslott \& Marks, 2020b). in the words of Nworgu, Pate and Obi (2017) "The essence of vaccination of immigrants from yellow fever and other infectious diseases is to ensure the well-being of not only the travellers but also that of the citizens of countries where the travellers are heading to" (Nworgu, Pate \& Obi, 2017:116).

\section{Mandatory Covid-19 vaccine for Churches}

This paper has shown that the majority, if not all, of the major religions of the world have voiced positions aimed at protecting the health and well-being of their followers. The Christian religion is no exception to this obligation. Although only a few Christian groups such as the South African National Christian Forum (SANCF) have spoken out against the compulsory Covid-19 vaccination (Pillay, 2021; Swart, 2021), the moral reasons for calling for a compulsory Covid19 vaccination are too compelling to ignore or allow debates on this uneasy discussion to continue while Covid-19 mortality rates continue to rise unabated. Thus, it is fundamental to understand that all religious organizations, including Christian churches, like all other social institutions, are not exempt from health and safety laws that require institutions to take all reasonable steps to ensure a safe environment for people on their premises. It is therefore a matter of course that all Christian churches share the commitment along with respectable Christian leaders such as Pope Francis, Bishop Hilarion Kapral, Archbishop Elpidophoros, Archbishop Thabo Makgoba and many other respected leaders who see the need for Covid19 mandatory vaccination in order to maintain public health. Following the example of a number of South African universities such as Stellenbosch University (SU), the University of Cape Town (UCT), the University of the Free State (UFS) and other organizations that are considering compulsory Covid-19 vaccination in order to allow safe return of their constituencies back to their respective premises, churches too must consider this essential measure in order to keep their congregants safe from this deadly virus called Covid-19.

If religious or Christian advocacy for vaccination and reasons for vaccination in general, or both smallpox and yellow fever vaccinations are anything to go by, then requiring Covid-19 vaccination for church attendance is both morally good and in the best interests of congregants' public health. Churches, like all other social institutions in society, rely on attainment of Covid-19 herd immunity or adequate Covid-19 vaccination coverage to facilitate the much-needed return to normal church practices where Christians will once again enjoy the in-person church attendance, freely worship and pray communally under one roof without fears of being infected with Covid-19. Just as churches have adhered to masking requirements and social distancing measures to ensure public health or limit exposure to Covid-1910, they

\footnotetext{
${ }^{10}$ https://www.gov.za/covid-19/alert-level-3-coronavirus-covid-19-lockdown - Disaster Management Act: Regulations during Covid-19
} 
must also respond to the issue of the mandatory Covid-19 Vaccination by making decisions or considerations that put the health, safety and life of their constituents as the first priority.

\section{Some Christian Bible views}

Talbot (2021), states that Holy Scripture informs us that both sickness and health come from God: "for he wounds, but he bands up; he shatters, but his hands heal" (Job 5:17-18; Hosea. $6: 1$ ). Health and matters of healing are attributed directly to God (Exodus 15:26; Deuteronomy 32:39; Luke 4:16-21) or it is in fact is mediated to us through his priestly, prophetic, or ecclesiastical representatives (1 Kings 17:17-24; 2 Kings 5:1-14; Mark 6:7-13; Acts 3:1-10; 9:32-35; James 5:14-15). Some references to physicians and healing are found in the following verses of the Holy Bible.

Jeremiah 8:22 ESV "Is there no balm in Gilead? Is there no physician there? Why then has the health of the daughter of my people not been restored?"

\section{Mark 2:17 ESV "And when Jesus heard it, he said to them, "Those who are well have no need}

Colossians 4:14 ESV "Luke the beloved physician greets you, as does Demas. of a physician, but those who are sick. I came not to call the righteous, but sinners."

2 Chronicles 16:12 ESV "In the thirty-ninth year of his reign Asa was diseased in his feet, and his disease became severe. Yet even in his disease he did not seek the Lord, but sought help from physicians."

Luke 10:30-35 ESV "Jesus replied, "A man was going down from Jerusalem to Jericho, and he fell among robbers, who stripped him and beat him and departed, leaving him half dead. Now by chance a priest was going down that road, and when he saw him he passed by on the other side. So likewise a Levite, when he came to the place and saw him, passed by on the other side. But a Samaritan, as he journeyed, came to where he was, and when he saw him, he had compassion. He went to him and bound up his wounds, pouring on oil and wine. Then he set him on his own animal and brought him to an inn and took care of him."

It is clear that God commonly exercises his providential care for his people through the world's commonplace structures and procedures. People tend to reap the fruit of their ways, good or bad (Proverbs 14:14). In any event it is clear that doctors are divinely instructed instruments through which powers which God has built into the created order may become available for human well-being (Talbot, 2021). This is why the physician Luke was held in high esteem in the apostle Paul's following. The most convincing reason to overcome that reluctance to take a vaccine is what Jesus described as the second great commandment after loving the Lord your God - love your neighbour as yourself. Christians are called to sacrifice in His name as Jesus offered himself as the perfect sacrifice to atone for all the sins of humanity. Paul in his letter to the Philippians says "Let each of you look not only to his own interests, but also to the interests of others" and in Ephesians, he states "submit to one another out of reverence for Christ." In fact, any human being, simply by being made in God's image, can serve as a Godgiven instrument to discover some feature of the creation that conveys the health and healing that, ultimately, comes only as a gift from God. The COVID vaccine is, could well be one of those gifts (Talbot, 2021).

\section{Conclusion}

This paper consisted of three sections. First, the history of vaccination in general was discussed. Second, an overview of some important religious beliefs about vaccination in general was discussed. Third, the views of Christian denominations such as the Roman Catholic Church, Orthodox Churches and Protestant Churches have been taken into account to propose a strong case for compulsory Covid-19 vaccination for churches in South Africa. The most important conclusion that can be drawn from this work is that the major world religions strongly support vaccination in general and also support the urgent need for 
compulsory vaccination against Covid-19, as has been shown by major denominations within Christianity.

There are actually very few religions who have documented, doctrinal reasons for not trusting in immunization for Covid-19. For some Christians, the pronouncement of whether to vaccinate or not comes down to the origins of the vaccines and many are thus sceptical of getting a jab. We would do well to remember that Jesus acknowledged himself as the great physician when he was disparaged for spending time with social undesirables like tax collectors and he stated: "It is not the healthy who need a doctor, but the sick."

\section{References}

ACNS, News. (2021). Anglicans join other faith leaders in global call for an end to 'vaccine nationalism.' [online] Available at: https://www.anglicannews.org/news/2021/05/anglicansjoin-other-faith-leaders-in-global-call-for-an-end-to-vaccine-nationalism.aspx [Accessed 1 Nov. 2021].

Agbiji, O.M. \& Swart, I. (2015). RELIGION AND SOCIAL TRANSFORMATION IN AFRICA: A CRITICAL AND APPRECIATIVE PERSPECTIVE, Scriptura, 114.

Albert, M.R., Ostheimer, K.G. \& Breman, J.G. (2001). The Last Smallpox Epidemic in Boston and the Vaccination Controversy, 1901-1903, New England Journal of Medicine, 344(5), 375379.

Anglicanchurchsa.org. (2021.). Provincial Synod backs Covid-19 vaccinations - Anglican Church of Southern Africa. [online] Available at: https://anglicanchurchsa.org/provincialsynod-backs-covid-19-vaccinations/ [Accessed 1 Nov. 2021].

BBC News. (2021). Covid: Dalai Lama urges others to get vaccinated as he receives first shot. [online] 7 Mar. Available at: https://www.bbc.com/news/world-asia-india-56310274 [Accessed 2 Oct. 2021].

Belongia, E.A. \& Naleway, A.L. (2003). Smallpox vaccine: the good, the bad, and the ugly. Clinical medicine \& research, 1(2),87-92.

Berenbaum, A. (2014). Healthcare Workers' Religious Objections to Mandatory Influenza Vaccination: Examining Title VIl's Religious Accommodation Requirement. Louis Jackson National Student Writing Competition. [online] Available at: https://scholarship.kentlaw.iit.edu/louis_jackson/3 [Accessed 28 Oct. 2021].

Besent, M. (2021). Mandatory COVID-19 vaccination for Anglican clergy: Makgoba. [online] Available at: https://www.sabcnews.com/sabcnews/mandatory-covid-19-vaccination-foranglican-clergy/ [Accessed 1 Nov. 2021].

Blignaut, J. (2013). Calling the shots on vaccination: when is the state justified in overturning a refusal to vaccinate? open.uct.ac.za. [online] Available at: https://open.uct.ac.za/handle/11427/4682 [Accessed 2 Nov. 2021].

Burger, R., Buttenheim, A., English, R., Maughan-Brown, B., Köhler, T. \& Tameris, M. (2021). COVID-19 vaccine hesitancy in South Africa: Results from NIDS-CRAM Wave 4. [online] Available at: https://cramsurvey.org/wp-content/uploads/2021/05/3.-Burger-R.-ButtenheimA.-English-R.-Maughan-Brown-B.-Kohler-T.-_-Tameris-M.-2021.-COVID-19-vaccinehesitancy-in-South-Africa-Results-from-NIDS-CRAM-Wave-4.pdf. 
Bush, A. (2012). Vaccination in Halakhah and in Practice in the Orthodox Jewish Community. [online] Available at: https://hakirah.org/Vol13Bush.pdf [Accessed 14 Oct. 2021].

Byrne, K. (2007). The One and Many God's of Hinduism, Crossroads, 1(2), 15-27.

Cha, S.-H. (2012). The history of vaccination and current vaccination policies in Korea, Clinical and Experimental Vaccine Research, [online] 1(1),3. Available at: https://www.ncbi.nlm.nih.gov/pmc/articles/PMC3623509/.

Chipkin, I. and Leatt, A., (2011), 'Religion and revival in post-apartheid South Africa', FOCUS Chukwuma, O.G. (2021). The impact of the COVID-19 outbreak on religious practices of churches in Nigeria, HTS Teologiese Studies / Theological Studies, 77(4).

Cohen, S.J.D. (2006). FROM THE MACCABEES TO THE MISHNAH Second Edition. [online] Available at: http://www.baytagoodah.com/uploads/9/5/6/0/95600058/262596668-from-themaccabees-to-the-mishnah.pdf [Accessed 16 Oct. 2021].

CRPC, Statement (2016). City Reformed Presbyterian Church Statement on Vaccination. [online] Available at: https://www.cityreformed.org/uploads/4/4/0/9/44096805/crpc_vaccination_statement_final.pd f [Accessed 31 Oct. 2021].

De Haas, B. \& Mud, N. (2020.). [online] Available at: https://frw.studenttheses.ub.rug.nl/3400/1/Master\%27s\%20Thesis_Nienke\%20Mud_255595 $6 \% 20 \% 281 \% 29$.pdf.

Dubé, E., Gagnon, D., Nickels, E., Jeram, S. \& Schuster, M. (2014). Mapping vaccine hesitancy-Country-specific characteristics of a global phenomenon, Vaccine, 32(49), 66496654.

Ebrahim, A.F.M. (2014). Vaccination in the Context of Al-Maqasid Al-Shari ah : Objectives of Divine Law and Islamic Medical Jurisprudence, Oman Chapter of Arabian Journal of Business and Management Review, 3(10), 44-52.

Enlingheuser, S. (2019). Testimony of Steven Enlingheuser: Informational Hearing on the State's Religious Exemption. [online] Available at: https://www.cga.ct.gov/kid/related/20190513_Informational\%20Hearing\%20on\%20the\%20St ate $\% 27 s \% 20$ Religious\%20Exemption/Testimony/Testimony\%20Steven\%20Enlingheuser.pd f

Florindo, H.F., Kleiner, R., Vaskovich-Koubi, D., Acúrcio, R.C., Carreira, B., Yeini, E., Tiram, G., Liubomirski, Y. \& Satchi-Fainaro, R. (2020). Immune-mediated approaches against COVID-19, Nature Nanotechnology, 15(8), 630-645.

Fredriksen, P. 1951- (2003). What 'Parting of the Ways'?: Jews, Gentiles, and the Ancient Mediterranean City. The ways that never parted, [online] p.35. Available at: https://ixtheo.de/Record/1444053531 [Accessed 16 Oct. 2021].

Frierson, J.G. (2010). The yellow fever vaccine: a history, The Yale journal of biology and medicine, 83(2), 77-85. 
Gear, J.H. (1986). The history of virology in South Africa, South African Medical Journal = Suid-Afrikaanse Tydskrif Vir Geneeskunde, [online] Suppl, pp.7-10. Available at: https://pubmed.ncbi.nlm.nih.gov/3535124/ [Accessed 2 Nov. 2021].

Gerrish, B.A. (2004). The old Protestantism and the new: essays on the Reformation heritage, London; New York: T \& T Clark International.

Githahu, M. (2021). Archbishop Makgoba's support for mandatory vaccination of clergy. [online] Available at: https://www.iol.co.za/capeargus/news/archbishop-makgobas-supportfor-mandatory-vaccination-of-clergy-a7af873d-5657-4cd8-8258-fd65c3c4166a [Accessed 1 Nov. 2021].

Githahu, M. (2021). Faith groups launch campaign to vaccinate $70 \%$ of their flock. [online] 28 Sep. Available at: https://www.iol.co.za/capeargus/news/faith-groups-launch-campaign-tovaccinate-70-of-their-flock-b87d4bf8-26ce-4f0e-8710-fb594a793cff [Accessed 29 Oct. 2021].

Gopez, J.M.W. (2021). Building public trust in COVID-19 vaccines through the Catholic Church in the Philippines, Journal of Public Health, 43(2).

Grabenstein, J.D. (2013). What the World's religions teach, applied to vaccines and immune globulins, Vaccine, 31(16), pp.2011-2023.

Helble, M. (2007). ON THE INFLUENCE OF WORLD RELIGIONS ON INTERNATIONAL TRADE. 209 On the Influence of World Religions on International Trade, [online] 7. Available at: https://jpia.princeton.edu/sites/jpia/files/2006-11.pdf [Accessed 23 Oct. 2019].

Henderson, D.A. (1997). Edward Jenner's vaccine. Smallpox Vaccine. [online] Available at: https://www.ncbi.nlm.nih.gov/pmc/articles/PMC1381857/pdf/pubhealthrep00041-0030.pdf.

Heymann, D.L. \& Aylward, R.B. (2006). Mass vaccination: when and why, Current topics in microbiology and immunology, [online] 304, 1-16. Available at: https://www.ncbi.nlm.nih.gov/m/pubmed/16989261/.

Hillyer, J.F. \& Christensen, B.M. (2002). Characterization of hemocytes from the yellow fever mosquito, Aedes aegypti, Histochemistry and Cell Biology, 117(5), 431-440.

Holy Bible, ESV 2021

Hussain, A., Ali, S., Ahmed, M. \& Hussain, S. (2018). The anti-vaccination movement: A regression in modern medicine. Cureus, [online] 10(7). Available at: https://www.ncbi.nlm.nih.gov/pmc/articles/PMC6122668/.

IAC, Immunisation Advisory Centre. (2016). Vaccine development. [online] Available at: https://www.immune.org.nz/vaccines/vaccine-development.

Jaja, I.F., Anyanwu, M.U. \& Iwu Jaja, C.-J. (2020). Social distancing: how religion, culture and burial ceremony undermine the effort to curb COVID-19 in South Africa, Emerging Microbes \& Infections, 9(1), pp.1077-1079.

Kiboneka, A. (2021). Understanding childhood immunizations, their serological interpretation and vaccines - A review article, World Journal of Advanced Research and Reviews, 10(3), 233-238. 
Kling, S. (2009). Vaccination and Ethical Issues. [online] Available at: https://www.mm3admin.co.za/cms/cpd/articles/vaccination-and-ethical-issues.pdf [Accessed 2 Nov. 2021].

Kotzé, H. \& Loubser, R. (2017). RELIGIOSITY IN SOUTH AFRICA: TRENDS AMONG THE PUBLIC AND ELITES, Scriptura, 116(1).

Krieger, L. (2015). Why religions don't oppose vaccines. [online] Available at: https://www.mercurynews.com/2015/01/31/why-religions-dont-oppose-vaccines/ [Accessed 2 Oct. 2021].

Lee, D. (1998). Yellow Fever and the Slave Trade: Coleridge's 'The Rime of the Ancient Mariner.' ELH, [online] 65(3), pp.675-700. Available at: https://www.jstor.org/stable/pdf/30030199.pdf [Accessed 3 Nov. 2021].

Letšosa, R. (2021). What has the beast's mark to do with the COVID-19 vaccination, and what is the role of the church and answering to the Christians? HTS Teologiese Studies/Theological Studies, 77(4).

Mbiti, J.S. (1999). African Religions and Philosophy, $2^{\text {nd }}$ ed. Oxford: Heinemann

Metzner, R. (1996). THE BUDDHIST SIX-WORLDS MODEL OF CONSCIOUSNESS AND REALITY. The Journal of Transpersonal Psychology, [online] 28(2). Available at: https://www.atpweb.org/jtparchive/trps-28-96-02-155.pdf [Accessed 1 Oct. 2021].

Miller, B.R., Monath, T.P., Tabachnick, W.J. and Ezike, V.I. (1989). Epidemic yellow fever caused by an incompetent mosquito vector. Tropical medicine and parasitology: official organ of Deutsche Tropenmedizinische Gesellschaft and of Deutsche Gesellschaft fur Technische Zusammenarbeit (GTZ), [online] 40(4), pp.396-399. Available at: https://pubmed.ncbi.nlm.nih.gov/2623418/ [Accessed 3 Nov. 2021].

Mir, D., Delatorre, E., Bonaldo, M., Lourenço-de-Oliveira, R., Vicente, A.C. \& Bello, G. (2017). Phylodynamics of Yellow Fever Virus in the Americas: new insights into the origin of the 2017 Brazilian outbreak, Scientific Reports, 7(1).

Mitchell, J.A. (1922). SMALL-POX AND 'AMAAS' IN SOUTH AFRICA, The Lancet, 200 (5172), 808-812

Monath, T.P. and Vasconcelos, P.F.C. (2015). Yellow fever, Journal of Clinical Virology, 64, pp.160-173.

Ndlovu, S. \& Nicolaides, A. (2021). Angels and Angelology: The Ministering Spirits and Elect 'sons of God', Pharos Journal of Theology, Volume 102 - Special Ed 1 (2021)

Nicolaides, A. (2021). Investigating the Holy Eucharist and the term 'people of God' according to the Eastern Orthodox Church, Pharos Journal of Theology, Volume 102.

Nicolaides, A. (2012). An assessment of justification according to Romans 4: 25, Ekklesiastikos Pharos, 94(1), 428-439.

Numrich, P.D. (2001). The Buddhist Tradition: Religious Beliefs and Healthcare Decisions. buddhism.lib.ntu.edu.tw, [online] p.15. Available at: http://buddhism.lib.ntu.edu.tw/DLMBS/jp/search/search_detail.jsp?seq=351322 [Accessed 2 Oct. 2021]. 
Nworgu, K.O., Pate, U. \& Obi, C. (2017). Press Coverage of Nigeria-South Africa Diplomatic Face-Off Over Yellow Fever Vaccination, Online Journal of Communication and Media Technologies, 7(2).

Occupational Health Clinic (2013). Immunizations and Religion | Vanderbilt Faculty \& Staff Health and Wellness. [online] Vumc.org. Available at: https://www.vumc.org/healthwellness/news-resource-articles/immunizations-and-religion.

Palazzani, L. (2018). Multicultural and interreligious perspectives on informed consent. The Christian perspective, Studia Bioethica, [online] 11(2). Available at: https://riviste.upra.org/index.php/bioethica/article/view/3688/2770 [Accessed 28 Oct. 2021].

Paris., J. (1993). THE SPIRITUALITY OF AFRICAN PEOPLES. [online] Available at: https://disa.ukzn.ac.za/sites/default/files/pdf_files/BtNov93.1015.2296.007.002.Nov1993.6.p df [Accessed 23 Sep. 2021].

Pelčić, G., Karačić, S., Mikirtichan, G.L., Kubar, O.I., Leavitt, F.J., Cheng-tek Tai, M., Morishita, N., Vuletić, S. \& Tomašević, L. (2016). Religious exception for vaccination or religious excuses for avoiding vaccination, Croatian Medical Journal, [online] 57(5), pp.516521. Available at: https://www.ncbi.nlm.nih.gov/pmc/articles/PMC5141457/.

Pierik, R. (2017). On Religious and Secular Exemptions. A Case Study of Childhood Vaccination Waivers. SSRN Electronic Journal.

Pillay, K. (2021). Christian group approaches Concourt to interdict Cyril Ramaphosa on mandatory vaccinations. [online] Available at: https://www.iol.co.za/news/politics/christiangroup-approaches-concourt-to-interdict-cyril-ramaphosa-on-mandatory-vaccinations-

1c1bd964-da7d-4b19-8dbe-c992108ad340 [Accessed 3 Nov. 2021].

Plotkin, S.A. (2011). Mass vaccination : global aspects : progress and obstacles. Berlin, London: Springer.

Prodromou, E. (2004). The Ambivalent Orthodox, Journal of Democracy, 15(2), pp.62-75.

Rashi, T. (2020) Jewish Ethics Regarding Vaccination. Public Health Ethics, Oxford University Press. Available at: https://doi.org/10.1093/phe/phaa022 [Accessed 12 Oct. 2021].

Reuters (2021). Vaccinate or repent, Russian church says amid hundreds of daily COVID-19 deaths. [online] 5 Jul. Available at: https://www.reuters.com/world/europe/vaccinate-orrepent-russian-church-says-amid-hundreds-daily-covid-19-deaths-2021-07-05/ [Accessed 29 Oct. 2021].

Rinpoche, T.Z. (1994). The healing Buddha : a practice for the prevention and healing of disease. Boston: Wisdom Publications.

Ruijs, W.L.M., Hautvast, J.L.A., van IJzendoorn, G., van Ansem, W.J.C., van der Velden, K. \& Hulscher, M.E. (2012). How orthodox protestant parents decide on the vaccination of their children: a qualitative study, BMC Public Health, [online] 12(1). Available at: https://www.ncbi.nlm.nih.gov/pmc/articles/PMC3434025/ [Accessed 19 Jan. 2020].

Ryall, D. (2001). The Catholic Church as a Transnational Actor. Non-state Actors in World Politics, pp.41-58. 
SACC, Pastoral letter. (2020). A General Pastoral Letter to the Churches From the Leaders of SACC Member Churches in COVID Time. [online] Available at: https://methodist.org.za/wpcontent/uploads/2014/10/A-Pastoral-Letter-by-SACC-Church-Leaders-in-COVID-TIme20200509.pdf [Accessed 31 Oct. 2021].

Sköld, P. (2012). The two faces of smallpox : a disease and its prevention in eighteenth- and nineteenth-century Sweden. [online] DIVA. Available at: https://www.divaportal.org/smash/record.jsf?pid=diva2\%3A531050\&dswid=-2760 [Accessed 2 Nov. 2021].

Smith, K.A. (2011). Edward Jenner and the Small Pox Vaccine, Frontiers in Immunology, 2.

Smith, P. (2021). Many Faith Leaders Say No to Endorsing Vaccine Exemptions. [online] 17 Sep. Available at: https://www.usnews.com/news/health-news/articles/2021-09-17/somefaith-leaders-say-no-to-endorsing-vaccine-exemptions [Accessed 29 Oct. 2021].

Smith, P.J., Wood, D. and Darden, P.M. (2011). Highlights of Historical Events Leading to National Surveillance of Vaccination Coverage in the United States, Public Health Reports, 126(2_suppl), 3-12.

Spaan, D.H., Ruijs, W.L.M., Hautvast, J.L.A. \& Tostmann, A. (2017). Increase in vaccination coverage between subsequent generations of orthodox Protestants in The Netherlands, The European Journal of Public Health, [online] p.ckw248. Available at: https://academic.oup.com/eurpub/article/27/3/524/2939509 [Accessed 31 Oct. 2021].

Stamouli, N. (2021). Science vs. religion as Greek priests lead the anti-vax movement, POLITICO. Available online at https://www.politico.eu/article/science-vs-religion-greecepriests-anti-vaccine-coronavirus-movement/

Stent, J. (2021). GROUNDUP : The banner that rings: Methodist church calls for religious organisations to support vaccination. [online] Daily Maverick. Available at: https://www.dailymaverick.co.za/article/2021-10-28-the-banner-that-rings-methodist-churchcalls-for-religious-organisations-to-support-vaccination/ [Accessed 31 Oct. 2021].

Stern, A.M. \& Markel, H. (2005). The History Of Vaccines And Immunization: Familiar Patterns, New Challenges. Health Affairs, [online] 24(3), 611-621. Available at: https://www.healthaffairs.org/doi/full/10.1377/hlthaff.24.3.611.

Stern, A.M. and Markel, H. (2005). The History Of Vaccines And Immunization: Familiar Patterns, New Challenges. Health Affairs, [online] 24(3), 611-621. Available at: https://www.healthaffairs.org/doi/full/10.1377/hlthaff.24.3.611.

Sulaiman, K.-D.O. (2014). An Assessment of Muslims Reactions to The Immunization of Children in Northern Nigeria, Medical Journal of Islamic World Academy of Sciences, 22(3), 123-132.

Swart, S. (2021). LETTER TO THE EDITOR: The ACDP is not opposed to vaccines, but we are opposed to mandatory Covid-19 vaccinations. [online] Daily Maverick. Available at: https://www.dailymaverick.co.za/article/2021-10-07-the-acdp-is-not-opposed-to-vaccinesbut-we-are-opposed-to-mandatory-covid-19-vaccinations/ [Accessed 19 Oct. 2021].

Sweetman, W. \& Malik, A. (2016). Hinduism in India: Modern and Contemporary Movements. [online] Google Books. SAGE Publications India. Available at: https://books.google.co.za/books?hl=en\&lr=\&id=XW02DAAAQBAJ\&oi=fnd\&pg=PA194\&dq= 
Hinduism+and+healing+\&ots=IGvNckzWmc\&sig=DB4p_vrVH-3WcPQ6dw6jjMA-

$6 \mathrm{eE} \&$ redir_esc $=\mathrm{y} \# \mathrm{v}=$ onepage $\& \mathrm{q}=$ Hinduism\%20and\%20healing $\& \mathrm{f}=$ false [Accessed 3 Oct. 2021].

Syed Alwi, S.A.R., Rafidah, E., Zurraini, A., Juslina, O., Brohi, I.B. \& Lukas, S. (2021). A survey on COVID-19 vaccine acceptance and concern among Malaysians, BMC Public Health, 21(1).

Talbot, M. (2021). The Bible and COVID Vaccines, CPT. Available online at: https://www.pastortheologians.com/articles/2021/9/16/the-bible-and-covid-vaccines

Tenzlng, T. (1996). Karma and Rebirth in Buddhism. [online] Available at: https://www.repository.cam.ac.uk/bitstream/handle/1810/243078/bot_1996_01_02.pdf?sequ ence $=1$ [Accessed 1 Oct. 2021].

The Guardian. (2021). Dalai Lama urges people to get Covid vaccine after having first dose. [online] the Guardian. Available at: https://www.theguardian.com/world/2021/mar/06/dalailama-urges-people-to-get-covid-vaccine-after-having-first-dose [Accessed 2 Oct. 2021].

Tyagi, A. and Carley, K.M. (2020). Divide in Vaccine Belief in COVID-19 Conversations: Implications for Immunization Plans. [online] Available at: https://www.medrxiv.org/content/medrxiv/early/2020/07/29/2020.07.23.20160887.full.pdf [Accessed 3 Oct. 2021].

Vanderslott, S. \& Marks, T. (2020). Travel restrictions as a disease control measure: Lessons from yellow fever, Global Public Health, pp.1-14.

Vanderslott, S. \& Marks, T. (2020b). Health diplomacy across borders: the case of yellow fever and COVID-19, Journal of Travel Medicine, [online] 27(5). Available at: https://www.ncbi.nlm.nih.gov/pmc/articles/PMC7454779/ [Accessed 31 Jan. 2021].

Vanderslott, S., Dadonaite, B. \& Roser, M. (2013). 'Vaccination'. Published online at OurWorldlnData.org. Retrieved from: 'https://ourworldindata.org/vaccination' [Online Resource]

Watkins, D. (2021). Pope Francis urges people to get vaccinated against Covid-19 - Vatican News. [online] Available at: https://www.vaticannews.va/en/pope/news/2021-08/pope-francisappeal-covid-19-vaccines-act-of-love.html.

WCC, Statement. (2021). Wisconsin Council of Churches: With one Body and one Spirit. [online]. Available at: https://www.wichurches.org/wp-content/uploads/2021/09/Returning-toChurch-v3-FINAL.pdf

Werner, K. (2016). A popular dictionary of Hinduism. Oxford, Eng.: Routledge, Printing.

WHO, World Health Organization (2020). WHO Director-General's opening remarks at the media briefing on COVID-19 - 11 March 2020. [online] www.who.int. Available at: https://www.who.int/director-general/speeches/detail/who-director-general-s-openingremarks-at-the-media-briefing-on-covid-19---11-march-2020.

Williams, J.T.B., Fisher, M.P., Bayliss, E.A., Morris, M.A. \& O'Leary, S.T. (2020). Clergy attitudes toward vaccines and vaccine advocacy: a qualitative study, Human Vaccines \& Immunotherapeutics, 16(11), 2800-2808. 
Williams, J.T.B., Nussbaum, A.M. \& O'Leary, S.T. (2019). Building Trust: Clergy and the Call to Eliminate Religious Exemptions, Pediatrics, [online] 144(4), p.e20190933. Available at: https://pediatrics.aappublications.org/content/pediatrics/early/2019/09/05/peds.20190933.full.pdf [Accessed 31 Oct. 2021].

Wiysonge, C.S., Ndwandwe, D., Ryan, J., Jaca, A., Batouré, O., Anya, B.-P.M. \& Cooper, S. (2021). Vaccine hesitancy in the era of COVID-19: could lessons from the past help in divining the future? Human Vaccines \& Immunotherapeutics, pp.1-3.

Wombwell, E., Fangman, M.T., Yoder, A.K. \& Spero, D.L. (2015). Religious barriers to measles vaccination. Journal of community health, [online] 40(3), 597-604. Available at: https://www.ncbi.nlm.nih.gov/pubmed/25315714/.

Woodall, J.P. and Yuill, T.M. (2016). Why is the yellow fever outbreak in Angola a threat to the entire world'?. International Journal of Infectious Diseases, 48, 96-97.

Woodburne, A.S. (1925). The Idea of God in Hinduism. The Journal of Religion, 5(1), 52-66.

WPR, World Population Review (2021). Religion By Country 2020. [online] worldpopulationreview.com. Available at: https://worldpopulationreview.com/countryrankings/religion-by-country.

Zainudin, H.E., Mohammad, K.A., Aris, A. \& Shahdan, I.A. (2018). Vaccination: Influencing Factors and View from an Islamic Perspective, IIUM Medical Journal Malaysia, 17(2).

Zakai, A. (1987). Reformation, History, and Eschatology in English Protestantism, History and Theory, 26(3), 300. 